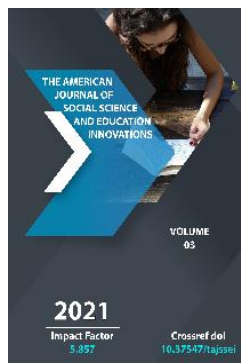

\title{
On The Principles And Methods Of Learning Writing In A Foreign Language (On The Example Of The Korean Language)
}

Nasiba Xakimboyevna Abdullaeva

Tashkent State Pedagogical University Named After Nizami Tashkent, Uzbekistan

Journal Website:

http://usajournalshub.c om/index,php/tajssei

Copyright: Original content from this work may be used under the terms of the creative commons attributes 4.0 licence.

\section{ABSTRACT}

Currently, teaching foreign languages is becoming relevant in connection with the introduction of new pedagogical. The student is faced with a number of facts related to the field of vocabulary, grammar, phonetics, and stylistics. In addition, simultaneously with the study of the language, one must also study the culture of its people - get acquainted with history, literature, economics, geography, everyday life, traditions, etc. The aim of this study is to explore innovative methods and techniques in teaching writing in Korean, and to determine the importance of learning Korean and writing literacy. The article reveals the features of teaching writing, namely active, passive and interactive methods and their application in the classroom in the Korean language.

\section{KEYWORDS}

Korean language, method, teaching principles, exercises, communication, complexity, accessibility, consistency.

\section{INTRODUCTION}

The relevance of research. In recent years of independence, the Republic of Uzbekistan has made a huge step not only in the field of politics, economics, culture, but also in the field of science and education. An important component is the comprehensive development of knowledge in the field of foreign languages. The study of languages is 
one of the main tasks in the implementation of the concept of lifelong education in Uzbekistan, which contributes to the formation of a creative, socially active and spiritually rich personality, highly qualified and competitive personnel who are ready to realize themselves both in a market economy and in interstate and intercultural relations.

One of the pressing issues is that when studying a foreign language, a student is faced with a number of facts that do not relate to the field of vocabulary, grammar, phonetics or stylistics, but rather to the correct presentation of their thoughts in writing. In addition, simultaneously with the study of the language, one must also study the culture of its people - get acquainted with history, literature, economics, geography, everyday life, traditions, etc. Along with mastering a foreign language, there is the assimilation of cultural knowledge and the formation of the ability to understand the speakers of another language, in this case, the Korean language.

\section{MAIN CONTENT}

The purpose of this study is to explore innovative methods and techniques in teaching writing in Korean. The following tasks follow from this goal: - to study the theoretical background and topical issues of research of innovative methods of teaching writing in a foreign language class; - to determine the importance of principles, innovative methods of teaching a foreign language and to study current trends and their relationship with teaching writing; - to identify the features of teaching writing, namely active, passive and interactive methods and their application in Korean language classes in connection with listening and reading.
In the course of this study, scientific and methodological materials of Korean and Russian methodological scientists, as well as materials in English, were studied. Despite active and popular research, many questions of the methodological plan leave a number of unresolved questions, in particular, a large number of works are devoted to the psychological aspects of learning a foreign language (V.A. Artemov, L.L. Blonsky, S.L. Bocharova, etc.) ... Other works are devoted to pedagogy and research on methodological activity at the level of pedagogical analysis and education (V.A. Slastenin, Ya.A. Komensky, P.I. Pidkasisty, E.V. Ilyenkov, etc.)

An important principle in teaching a foreign language is the principle of accessibility. In relation to most academic subjects, the use of this principle means "transition from easy to difficult", in other words, the presentation of educational material should be carried out as the growth and increase of complex material in a foreign language. In this case, the principle we are analyzing is used in teaching foreign languages in a transformed form. In its immediate meaning, this principle only works when selecting texts that should be available to learners in terms of linguistic material and cultural data, special exercises, assignments, etc. With regard to the presentation of the linguistic material of a foreign language, the direct use of this principle is inappropriate, for example, in the Korean language. As you know, in the Korean language, the greatest difficulties for students are caused by the use of an official-polite style. In the Korean language, as you know, there is a grammatical category of politeness and the form of polite forms in the transmission of someone else's speech. We must introduce students to this linguistic phenomenon in Korean despite the 
difficulties of learning. For example, in writing a letter, it is imperative to use words and particles such as 귀한, - 께, 올림, 드림, etc.

The scientific principle also requires close attention on the part of methodologists and teachers. With regard to most academic subjects, the principle of scientificity means communicating facts, patterns to students in accordance with the modern achievements of the science, the foundations of which are being studied. In the process of teaching foreign languages, we do not aim to master the theory of the corresponding language. Our task is to form linguistic consciousness, literacy, communication skills. It is not for nothing that linguistic and pedagogical grammar differ. Therefore, the principle of scientific character in relation to our academic subject should be perceived as the use of teaching methods that correspond to the modern achievements of pedagogy. In addition, in the teaching methodology, one should always remember that for all combinations and interactions of principles, the principle of activity remains important, which in teaching foreign languages, first of all, means the development of speech activity in learning, the need to bring the process of forming communicative skills closer to mastering a second language in natural conditions. Moreover, this principle means the predominant use of creative tasks, exercises, assignments, etc.

In the context of the modern understanding of the essence of teaching foreign languages as a process of forming a student's ability for intercultural communication, it would be unfair to limit the content of education only by focusing on the language experience in the native language. Active, passive and interactive teaching methods are important implementations. Of particular importance is the fact that the implementation of the principles of teaching foreign languages listed in the previous chapter of the dissertation orients the process of teaching foreign languages to the personality of the student as a whole. At the same time, the main thing is the formation of not only foreign language speech skills and abilities in him (the student), but also the entire totality of his cognitive and affective abilities, which are often not linguistic, but create the preconditions for the successful functioning of the latter. This means that in the modern model of teaching foreign languages, built on the principles of interconnected communicative, sociocultural and cognitive development of a student, the latter plays the role of a subject of the educational process and a subject of intercultural interaction.

According to the degree of activity of the teacher of students during the process, teaching methods can be divided into: 1) Passive: students act as an "object" of learning, who must assimilate and reproduce the material that is transmitted to them by the teacher - the source of knowledge. The main methods are lecture, reading, questioning. 2) Active: where students are the "subject" of learning, perform creative tasks, enter into a dialogue with the teacher. The main methods are creative assignments, student-to-teacher and teacher-to-student questions. 3) Interactive: from the English. (inter "between", act "action"): allowing you to learn to interact with each other, i.e. interactive learning - learning based on the interaction of all students, including the teacher. Before considering the development of writing skills in Korean by the above methods in the specified sequence, we note that the distinction made is somewhat conditional, which is associated 
with the need to make the presented material as clear as possible and more accessible. When conducting methodological research, the above methods, as a rule, are not used in isolation: they are often intertwined to the degree of cohesion and complement each other, which leads to obtaining objective results [7]. In addition, a reservation should be made regarding the completeness of the description of such a research method, which is a "pedagogical experiment".

Given the special importance of this method in modern research, it is advisable to give it a special place here (교사 의 음성 이나 녹음 자료 를 듣고 모방 과 암기를 하도록 훈련 단계 에서 의 단계 에서 발음, 억양 을 가르 칠 사용 사용 효과적). Exercises for teaching writing. Writing teaching includes various kinds of speech exercises: for teaching how to compose a written message; writing and speech exercises for working with printed text; written and speech exercises due to the process of reading, listening and oral communication. When listening to a foreign speech - listening - students can complete the following tasks: - compose a synopsis of the audiotext for pre-proposed keywords; • make notes to the printed reference signals while listening to the audio text; - in accordance with the assigned communicative task, extract information from the audio text and record it. Free dictation can be used. Here the teacher reads the audiotext paragraph by paragraph, the students write down what they have memorized; to facilitate the task, keywords or a plan are given in advance. When perceiving written speech, students draw up abstracts, a list of questions for discussion with a real or imaginary interlocutor, select a written lecture on cards, tables for oral communication on a specific topic or situation [4]. The practice of writing allows you to make a transposition of a printed text or audio text according to plan, from memory, or write down proposals for solving a specific issue or a specific problem. A set of lessons on the topic ends with a home essay (self-dictating - a written retelling of a part of the text or the entire text).

The ability to express your thoughts in a foreign language in writing should be developed consistently and constantly. For this, there are a number of reproductive and productive exercises [5]. All exercises are done in writing. For example, the following tasks are interesting: 1) restore the beginning and end of history; 2) restore the dialogue on the guiding remarks; 3) modify the text (message for conversation, dialogue for description); 4) describe an ambiguous situation in various texts and dialogues; 5) explain the contradiction between text and illustrative information; 6) reply to the letter by letter, telephone conversation, conversation, etc .; 7) select keywords that lead to a predetermined predetermined result, etc. $[1,2]$ The difference between these exercises is that they are performed only in writing, in terms of content they are of a speech creative or semi-creative nature, interesting and exciting for both students and teachers. Poems of famous poets are played out, monograms are used, letters are written to the address of fictional characters. funny stories are collectively composed. When introducing creative writing in the classroom, remember about the three most important conditions: the goals of teaching, principles, methods and techniques of teaching, as well as educational control. Writing a letter is a successful form of multifunctional exercise. To learn how to write 
a letter, you need to start with a series of speech exercises.

At the first stage, exercises can be offered to memorize speech formulas, cliches used in a letter, forms of written appeal to the addressee, ways of expressing gratitude, confirming receipt of a letter, hoping for a quick response, etc. [8]. Next comes the review of the text of the letters, the definition of schemes for various letters, the selection of individual phrases, supporting thoughts, keywords. Students analyze the texts of letters, characterize their authors, determine the nature of the letter (personal, family, business, problematic; letter expressing gratitude, congratulations, invitations, etc.), explore the means of expressing thoughts in letters of different style and nature, means of transition from one thought to another, etc. At the second stage, it is proposed, using sample phrases and keywords, to draw up a letter plan. Forms of appeal and other clichés should be consistent with the content, structure and style of the letter.

At the next stage of work, students are offered to compose a collective letter, then thematic letters on given situations, letters of a different nature (personal, family, business), a letterresponse to a request or wish of the addressee, a letter of initiative content or a letterresponse on a specific question to a specific addressee. It is possible to compose letters to different recipients with different target settings, but with identical content or making changes to the same message text [9]. You should work on drawing up questions to the addressee and determine their place in the letter. When teaching spelling in Korean, you need to consider reading and spelling rules. They are useful for writing words whose spelling is based on phonetic principles, i.e. such as 읽다 - read, 삶 - life, 옮기다 - move. Usually, neither cheating, nor dictations, nor naming by letters, nor taking into account the rules of reading can ensure that students master the spelling of difficult words effectively enough. Spelling words that are based on historical principles cause particular difficulties in learning to spell words.

Students should remember that when spelling, each letter is pronounced, each syllable as, for example, in the words 늙다 - old, 흙 - clay, etc. This work must be done at the initial stage of learning. By mastering spelling reading, students become proficient in writing and reading skills, which improves their speaking and speaking skills. Writing work is very helpful in teaching the skills of writing individual words, expressions and sentences, contributing to the development of visual memory in students. Students see what is written on the board first. Then everything is erased from the board, and the guys write from memory. To check the correctness of the spelling, the written text appears again, and the students themselves check the text. This is how they develop the ability to control themselves. All this work is being done gradually. When teaching a foreign language, students must master writing enough to help them master its lexical and grammatical material necessary for the development and improvement of oral speech and reading [3]. Writing also teaches students to write the letters of the alphabet; skills in translating speech sounds into spelling symbols: letters and syllables and their combinations; the ability of spelling correct spelling of words, combinations of words and sentences; written performance of various exercises that contribute to a better assimilation of 
educational material necessary for the development and improvement of oral speech and reading.

The acquisition of experience as a research method is also widely used in modern methodological research. The main task of such training can be considered to conduct a mass survey based on materials obtained as a result of the primary survey carried out, i.e. on the basis of the initially developed teaching methodology, which has already given positive results in the process of studying the desired object of research. For example:

선생 : 스미스 씨 / 한국 사람 / 한국말을 해요.

학생 : 스미스 씨가 한국 사람 처럼 한국말을 해요.

선생 : 그 아이 / 어른 / 행동해요.

학생 : 그 아이가 어른처럼 행동해요.

선생 : 하숙집 아주머니가 / 어머니 / 잘 해 주십니다.

학생 : 하숙집 아주머니가 어머니처럼 잘 해 주십니다

Sometimes, in teaching aids dedicated to teaching a foreign language, they especially emphasize as its leading characteristics such features as motivation, focus (appeal), emotionality and situationality. This, of course, is correct, but it is still not purely specific only for oral speech, since written speech also has the noted characteristics, which, however, are expressed using means other than those of oral communication. At the same time, it should be emphasized that, for obvious reasons, the measure of emotionality and situationality of oral speech is incomparably higher than that which can be observed in a written text, even describing situations of oral communication (play, movie script or TV show). This is due to the direct contact of the oral speech act, which is absent in the field of communication of written speech; there, as they say, an invisible contact is established only thanks to the very high skill of the author of the work. Psychologically, the factor of preparedness and unpreparedness of the statement is of great importance. Consider language exercises, for example, when buying something in a store, the buyer must say one or more phrases:

1. 저 책가방을 좀 보여주십시오.

2. 값이 얼마입니다?

3. 마음에 듭니다. 사겠습니다.

4. 돈 을 받으십시오.

5. 감사합니다.

This is a speech activity that is subordinated to a specific goal - buying a portfolio. But, carrying out this activity, the buyer also performed a number of actions, characterized by their more private goals: he turned to the seller with a request $/ 1 /$, asked him a question $/ 2 /$, informed about the desire to buy this thing / 3 /, offered to receive money $/ 4 /$, thanked the seller $/ 5 /$. To perform each of the five actions, he needed to perform several operations / find the right words, arrange them in a certain sequence, use the necessary endings in these words in order to establish a connection between them, make them as a question, request or statement, etc. I ... If a person does not speak the language well, each of the operations is performed 
slowly, with difficulty, since at first the operation, like an action, has a deliberate nature. One of the learning tasks is precisely that the operations are automated.

Exercises to find the specified elements of the text. When performing these exercises, students select in the text the lexical units indicated by the teacher or find grammatical structures, or determine the keywords or places in the text corresponding to the presented translation of one or two sentences, find the ending of the text, conclusions, etc. Exercises to find the basic information of the text. A large group of exercises such as table of contents of individual text fragments, drawing up a text plan in the form of questions or theses, defining "semantic milestones" of the text, etc. can be presented here. Exercises to shorten the text. This includes exercises such as breaking the text into autonomous fragments, finding sections containing the main idea, conveying a paragraph in one sentence, writing a conclusion about the content of the text. Exercises for the interpretation of the text. This group includes all exercises that start with the "why" question. Why is the text named so, why this scheme is proposed, why $X$ follows $Y$, etc. Exercises for anticipation. Such exercises include: read the title and define the content of the article, how events and relationships will develop further, how the described event can end, how the fate of the character will develop further, what could be done in such a situation, etc.

\section{CONCLUSIONS}

Exercises for transposition, i.e. exercises, during the implementation of which the transition from one code to another is made for example, oral retelling of a text or translation from a foreign language into a native one. Many exercises in informative reading represent the connection between teaching oral speech and reading, such as finding sentences of the text that are the answer to a question posed orally, oral transmission of the essence of what has been read in two or three sentences, oral retelling of text passages, etc. Lexical analysis is carried out, as a rule, in parallel with grammatical analysis, the main object of analysis here is word-formation formants, word combinations, stable word combinations. As you know, the goal of teaching foreign languages at the present stage, in particular, the Korean language, is the formation of communicative competence, which includes linguistic, thematic (extralinguistic and regional information), socio-cultural, compensatory, educational (ability to learn). The student must master such skills and abilities that would allow the most successful specialized training, would make it possible to carry out self-study of foreign languages in several directions: maintaining and improving the achieved level of communicative competence; learning a new foreign language.

In conclusion, we note that the scientific significance of the work lies in the methodological approach, taking into account innovative technologies in the educational process, which made it possible to develop a wide scientific description of the specifics of the methodology of teaching writing in Korean, to create new types of practical materials for teaching the Korean language. The practical significance of the work lies in the fact that based on the materials of this dissertation, it is possible to create textbooks, textbooks, methodological developments for teaching the Korean language, as well as in 
teaching special courses according to the curriculum of the university. Of course, the practical significance lies in the fact that our observations can be implemented in scientific research on the methodology of teaching the Korean language, in particular, grammar, writing and writing literacy.

\section{REFERENCES}

1. Arvanitopulo E.G. Educational projects in a foreign language for high school students | E.G. Arvanitopulo // Foreign languages. 2007. - No. 1.

2. Belyaeva A.P. Didactic principles of vocational training in vocational schools: Methodological guide. - $\mathrm{M}$ : Higher school, 1991.

3. Gostevskaya A.N., Babkina N.V. Interactive technologies in English lessons as a means of stimulating cognitive motivation of secondary school students // Novalnfo.Ru (Electronic magazine.) - 2017 - No. 61; URL: http://novainfo.ru/article/11632.

4. Emelyanova A.A. Teaching oral expression at the final stage at a technical university (based on the English language). AKD, Kiev, 1978.

5. Efremenko, V. A. Application of information technologies in foreign language lessons / V. A. Efremenko // Foreign languages at school. -2005. -No. 7.

6. Zimnyaya I.A. psychological aspects of teaching to speak a foreign language. M., 1978.

7. Kulish V. I. Application of information computer technologies in teaching foreign languages / V. I. Kulish // Language and communication in the context of culture: materials of the 5 th International scientific. Conferences. - -Ryazan, 2010.

8. Kochneva M.G. Teaching professionally directed dialogic speech in a non-linguistic university (based on the English language). AKD, Kiev, 1979.

9. Parikova G.V. New in the conduct of optional classes in non-linguistic universities. - Sat. Methodical notes on the teaching of foreign languages at the university. Issue 9. - M., 1974.

10. Ismatullayeva, N. R. (2020). Probability Prediction Strategy In Simultaneous Interpretation. Current Research Journal of Philological Sciences, 1(01), 1-6. 